\title{
The relationship between the level of state anxiety, trait anxiety, satisfaction with life and the selected biochemical parameters among oncological nurses
}

Przemyslaw Mateusz Domagala ( $\sim$ przemyslaw.domagala@gumed.edu.pl )

Gdanski Uniwersytet Medyczny https://orcid.org/0000-0002-3399-5556

Aleksandra Edyta Gaworska-Krzeminska

Gdanski Uniwersytet Medyczny

Research article

Keywords: psychological stress, biochemical markers of stress, nurses

Posted Date: August 6th, 2020

DOI: https://doi.org/10.21203/rs.3.rs-46974/v1

License: (c) (1) This work is licensed under a Creative Commons Attribution 4.0 International License.

Read Full License 


\section{Abstract}

Background. The working environment of nurses is associated with the presence of many stressors, for instance working the night shift and sleep deprivation, which may impair the secretion of various substances, such as prolactin, cortisol or cytokines. One of the groups particularly exposed to stress due to the specificity of work is oncological nurses.

Aim. The aim of this work is to undertake an attempt at assessing the impact of work environment on psychological and biochemical parameters of occupational exposure to stress among nurses and to examine mutual correlations between the studied variables.

Design and participants. Cross-sectional research design with the study group consisting of 90 registered nurses including 60 nurses working in oncology units and 30 primary health care nurses,

Method. A diagnostic survey was used to collect psychological and socio-demographic data. The following research tools were used: State-Trait Anxiety Inventory (STAI), Satisfaction With Life Scale (SWLS) and the authors' questionnaire. Also, serum levels of cortisol, prolactin, C-reactive protein, tumour necrosis factor $a$, interleukin 6 and urine cortisol levels were assessed.

Results. Psychological parameters significantly correlate with selected biochemical variables. A higher level of trait anxiety was associated with higher levels of proinflammatory cytokines in serum and a higher level of cortisol in urine.

Conclusions. This study provides evidence that work-related stress is associated with selected proinflammatory cytokines and hormones. There are psychological strategies and relaxation techniques which nurses should use as they significantly reduce the level of perceived stress and positively influence the values of the biochemical markers of stress.

\section{Highlights}

What is already known about the topic?

- Due to growing cancer incidence and an increase in staff shortage, oncology nurses are exposed to work-related stress and may struggle to maintain adequate work efficiency and satisfactory quality of life.

- There is insufficient research into the biochemical consequences of work-related stress and burnout among oncology nurses.

What does this paper add?

- The higher trait anxiety level among nurses was associated with a higher level of serum proinflammatory cytokines and urine cortisol. 
- Nurses with a higher level of state anxiety and trait anxiety reported a lower level of satisfaction with life.

\section{Background}

Stress is an extremely complex response, which can be defined in two inextricably linked aspects: as a biological and psychological phenomenon [Grygorczuk]. Two systems are primarily involved in its biological component: the hypothalamic-pituitary-adrenal system and the sympathetic adrenal system [Landowski]. The central nervous system sends signals to immune response cells through both of these systems. They produce cytokines and neurotransmitters which impact the functioning of the brain [Stokłosa]. In psychology, the concept of stress is approached in various ways but regardless of the type of approach, it should be described as an imbalance between the requirements and the capabilities of an individual [Heszen].

Work-related stress is the second most commonly reported health problem. Nearly a quarter of employees believe that occupational stress negatively affects their health. According to data from the European Agency for Safety and Health at Work, it accounts for $50-60 \%$ of absence from work due to health reasons. Potential sources of stress at work include working environment and conditions, working time distribution (shift patterns), workload and individual characteristics of the employee [Potocka]. It has been proven that workplace stress is associated with an increased incidence of many conditions, including metabolic syndrome or cardiovascular diseases, which are the leading causes of death in the world [Jarczok], [Esler et al.]. However, the consequences of occupational stress are multidimensional and their impact reaches beyond an employee's health. They also affect the functioning of the whole organisation, for instance through the deteriorating quality of work, absenteeism or increased employee turnover [Potocka].

\section{Neurophysiology of stress reaction}

Among the complexities of the biological mechanisms of stress, two systems should be distinguished: the hypothalamic-pituitary-adrenal axis (HPA) and the sympathetic adrenal system [Landowski], [Padgett, Glaser], [Foley, Kirschbaum]. The central nervous system sends signals through both these systems to the lymphoid organs, which are most often innervated by the noradrenergic fibres. Close relationships may develop between immune cells (lymphocytes and macrophages) and nerve endings. Norepinephrine directly affects $T$ and $B$ lymphocytes and, consequently, their activity. In peripheral lymphatic organs, however, this neurotransmitter intensifies the primary humoral response [Stokłosa]. Stress induces excessive corticoliberin (CRH) secretion in the hypothalamus - the first link in HPA. CRH secretion can also be stimulated by cytokines, primarily interleukin 1 . This neurohormone, in turn, induces corticotropin (ACTH) secretion by the anterior pituitary gland [Zimecki]. This reaction can also be induced by cytokines such as IL-1, IL-6 and TNFa [Stokłosa]. The adrenocorticotropic hormone induces the secretion of adrenal corticosteroids, mainly cortisol [Zimecki]. This leads to immunosuppression through transcriptional and post-transcriptional inhibition of cytokine expression but the same mechanism activates receptor 
expression for the same the cytokines [Stokłosa]. In addition, glucocorticosteroids enhance the effects of catecholamines. Negative feedback may become inefficient because the activation of the limbic system and the hypothalamus outweighs their feedback inhibition caused by an increase in blood cortisol level [Zimecki].

The effects of the hormones secreted as a response to stress, primarily catecholamines and cortisol, but also growth hormone (somatotropin) and prolactin on the cells of the immune system induce the secretion of cytokines such as IL-1, IL- 6 and TNFa. The increase in the concentration of the last two cytokines may lead to major health disorders [Glaser]. It should be noted that the immune system cells may be an ecotopic source of hormones but they primarily have autocrine and paracrine effects. They mostly produce pituitary hormones such as prolactin or corticotropin. It is worth noting that they cannot be instantly released because they are not stored in cells - they must be produced de novo [Stokłosa].

Like other cytokines, interleukin 6 has pleiotropic effects. It is secreted mainly by monocytes and macrophages and plays an important role in the acute phase response, which is part of non-specific immunity, anti-infective response and haemopoiesis [Gołąb]. It plays a major role in the production of the C-reactive protein (CRP) in the liver [Yudkin]. It is also one of the major pyrogens, as are IL-1 and TNFa. A relationship has been shown between increased levels of interleukin 6 and the incidence of many diseases such as cancer, cardiovascular diseases, type 2 diabetes, osteoporosis [Glaser], rheumatoid arthritis [Gołąb], depression [Służewska et al.] and intestinal diseases [Atreya, Neurath]. Higher interleukin 6 levels have been associated with an increased risk of death from cardiovascular conditions [Su et al.], lung diseases [De Lauretis et al.], and age because they are observed in elderly patients [Harris et al ].

Tumour necrosis factor a (TNFa) is produced primarily by macrophages [Chu]. This cytokine causes apoptosis and necrosis of cancer cells. The receptors for this cytokine are located on the surface of almost every human cell. Its effects include enhancing the cytotoxicity of macrophages and monocytes. TNFa and IL-6 stimulate B cell proliferation and differentiation [Gołąb]. Tumour necrosis factor $a$ is the key mediator of acute and chronic inflammation, it plays an important role in many autoimmune diseases such as multiple sclerosis, systemic sclerosis, rheumatoid arthritis and Crohn's disease [Chu]. Chronically elevated TNFa levels lead to cachexia, protein and lipid catabolism [Gołąb]. Increased plasma TNFa and IL-6 levels have been shown to correlate positively with higher insulin resistance associated with obesity [Kern], psoriasis [Arican et al.], systemic lupus erythematosus activity [Sabry et al.], and also with sarcopenia in elderly patients [Visser].

\section{The psychological approach to stress}

The concept of stress is debated in psychology and there are many approaches to describing this phenomenon. Nearly all of them are based on two dimensions. One refers to extrinsic factors, while the other refers to intrinsic factors. The differences in particular approaches consist in highlighting and describing those factors [Terelak]. 
The first trend involves emphasising extrinsic factors and is based on stimuli as described by Irwing Janis who examined patients undergoing surgery. The argument against this approach is its ambiguity because individual differences make a certain event stressful for one person when it is not stressful for someone else. The second tendency relates to specific human responses - reactions. David Mechanic was in favour of this approach, describing stress as a reaction of discomfort. This approach does not account the overall stress response and proved to be inconclusive [Heszen].

Currently, most psychologists define stress as a transaction between the requirements of the environment and the capabilities of an individual. Susan Folkman and Richard Lazarus subscribe to this approach to stress in their popular paradigm [Grygorczuk].

Anxiety is a concept which positively correlates with stress response [Roberti et al.]. It has been shown that professions which involve helping others are associated with an increased occurrence of negative emotions, including anxiety, under the influence of stressors [Kliszcz et al.]. Many researchers have expressed the view that anxiety is an objectless emotion so it is not directly related to a stress factor and may occur in a completely safe situation. It may also appear in contact with an object which is only a potential source of danger. Anxiety is accompanied by autonomic nervous system stimulation, which is manifested in increased epinephrine, norepinephrine and cortisol secretion [Werka, Zagrodzka]. In the popular approach proposed by Spielberger two types are distinguished: state anxiety and trait anxiety. The former, state anxiety, is defined a subjective, conscious and transient situational condition, which is accompanied by stimulation of the autonomous system. Trait anxiety is defined by Spielberger as an acquired behavioural disposition which determines an individual's perception of objectively harmless situations as threatening and causing a disproportionately strong anxiety reaction. Spielberger et al. designed the State-Trait Inventory Surveys (STAI) [Wrześniewski et al.] for assessing state and trait anxiety.

\section{Nurses' work environment and levels of stress, anxiety and satisfaction with life}

Stressors are common in the environment in which nurses work. Emotionally charged relationships with patients should be emphasised as one of such stressors. What is more, maintaining attentional focus, constant observation, instant response to dynamic changes in a patient's condition, feelings of lack of control, interpersonal conflicts, inability to alleviate the patient's ailments or feelings of not living up to expectations, are all important sources of nurses' occupational stress [Ogińska-Bulik], [Khamisa et al.]. Psychological stress is one of the components of burnout syndrome. It is more common in helping professions, for instance, nurses, doctors, therapists and social workers. This syndrome consists of three elements: emotional exhaustion, depersonalization and a reduced sense of personal accomplishments [Maslach et al.], [Wilczek-Rużyczka]. One study found that burnout levels correlate positively with the number of medical errors made by trainee doctors [West et al.]. This suggests that there may be similar dependencies for other professions, including nurses. 
Among nurses, certain groups are particularly exposed to stress and the resulting burnout syndrome, i.e. oncological nurses [Demanded, Gaworska-Krzemińska], [Emilia et al.], [Emold et al.], [Gomez-Urquiza et al.], [Potter et al.], pediatric and psychiatric nurses [Sęk]. Due to the increasing number of cancer patients, the need for oncology nurses' services [Yu et al.] is also increasing. A metaanalysis by Toh et al. revealed a correlation between professional dissatisfaction, stress and burnout and shortages of nursing staff in oncology units. Stress, lack of job satisfaction and burnout may lead to resigning from working with oncology patients. In turn, the shortage of oncology nurses and excessive workload have a negative impact and contribute to more stress, job satisfaction and burnout [Toh et al.]. The work of nurses in oncology wards is also associated with a lower, subjectively assessed quality of life [Ergün et al.]. In addition, as a result of occupational stress, oncology, hospice, emergency, pediatric and other nurses become susceptible to secondary post-traumatic stress disorder (also referred to as "compassion fatigue") [Beck]. This condition is the result of the exposure to individuals who have experienced trauma [Wang et al.]. Oncology nurses most often reported difficulties in falling asleep, irritability, obtrusive thoughts about patients, reduced activity level and the sense of foreshortened future, which is common in post-traumatic stress disorder [Beck]. In addition, compassion fatigue can reduce the quality of nursing care [Wang et al.]. The results from two Chinese studies involving large groups of oncological nurses indicate that the study groups of nurses had a low quality of professional life [Wang et al.], [Yu et al.]. A higher level of compassion fatigue was revealed by nurses with more years of professional experience and passive methods of coping with stress. Cognitive empathy, support and training received from organizations counteracted the low level of professional life quality, whereas passive coping with stress and neuroticism negatively impacted the quality values [Yu et al.].

Increased levels of occupational stress can also contribute to accumulating suppressed negative emotions including anxiety in people with a high level of socialization. This may lead to developing psychosomatic disorders, such as headache, appetite disorders, insomnia, or menstrual cycle disorders [Jin et al.], [Kane], [Kliszcz et al.]. The study conducted by Nyklewicz and Krajewska-Kułak suggests that death is a strong predictor of state anxiety in nurses work. What is important, the vast majority of respondents showed inefficient ways of coping with stress [Nyklewicz, Krajewska-Kułak]. Studies conducted among Australian nurses have revealed that elevated levels of state anxiety are associated with chronic fatigue, mood disorders and external locus of control [Samara et al.].

\section{Methods}

\section{Aim}

The aim of this paper is to assess the relationship between state anxiety, trait anxiety and life satisfaction, and the selected biochemical parameters of occupational exposure to stress among oncological nurses.

\section{Design and participants}


The study group consisted of 60 oncological nurses, i.e. subjects whose exposure to occupational stress and the consequent burnout is above average as indicated by previous studies. The control group consisted of 30 primary health care nurses. The study was conducted after obtaining approval from the Independent Bioethics Commission for Research at the Medical University of Gdańsk (NKBBN / 411 / 2015-2016). Obtaining the consent of the management of the institutions where the study was conducted was an obligatory condition. The participation in the study was voluntary and required the informed consent of respondents. The respondents were informed on how to complete the questionnaires. The laboratory analyzes were performed at the Central Clinical Laboratory of the University Clinical Centre in Gdańsk and all participants received their results. The study included subjects who worked as a nurse, worked in oncological units (study group), or in the primary health care (control group) and had at least 6 months of work experience in a given type of facility. Nurses with physiological conditions (e.g. pregnancy or lactation) or pathological conditions (e.g. hyperprolactinemia, adrenal gland disorders, autoimmune diseases, medications) which affected the level of examined biochemical parameters were excluded from the study.

\section{Method}

A blood sample was collected for testing at 8:00 along with the first urine sample. Serum levels of reactive protein C (CRP), prolactin, cortisol, interleukin 6 (IL-6) and tumour necrosis factor a (TNFa) were tested. Urine was tested for cortisol levels. In addition, standardized psychological questionnaires were used: State-Trait Anxiety Inventory (STAI) by Spielberger and Satisfaction With Life Scale (SWLS) by Diener, and an original survey questionnaire was used to analyse the demographic variables. Nurses were asked to complete the questionnaires immediately after venous blood collection for laboratory tests. On the day of the examination, the nurses were on the day shift at work.

\section{Statistical analysis}

All statistical calculations were performed with the use of the statistical package StatSoft. Inc. (2014). STATISTICA (data analysis software system) version 12.0. The W Shapiro-Wilk test was used to verify whether the quantitative variable originated from a standard distribution population. The Leven test was used to test the equal variance hypothesis. The significance of the differences between the two groups (independent variable model) was tested with the Student's t-test (or Welch's test when the assumption of homogeneity of variance is not met) or Mann-Whitney's $U$ test (when the conditions of the Student's t-test applicability are not met or for ordinal scale variables). The significance of the differences between more than two groups was verified with the F (ANOVA) or Kruskal-Wallis test (when ANOVA applicability conditions were not met). In the case of statistically significant differences between groups, post hoc tests (for Tukey F test and Kruskal-Wallis Dunn test) were used. Chi-square tests of independence were used for qualitative variables (Yates correction for cell count below 10, checking Cochran conditions, exact Fisher test). 
A correlation analysis with the Pearson and/or Spearman correlation coefficients was used to determine the association between force and direction between variables. For all the calculations the level of significance was set at $p \leq 0.05$.

\section{Results}

The results of psychological questionnaires were interpreted in three respects. The first one was the raw sum of points obtained. The second one was a sten score consistent with the standardization of the questionnaires used in the study. The third one was the interpretation of the obtained sten scores, which were characterized as low sten from 1 to 3 , average sten from 4 to 7 , or high sten from 8 to 10 .

The results of biochemical tests were interpreted within or above normal value range as per the reference values of the Central Clinical Laboratory of the University Clinical Centre in Gdansk, Poland.

No statistically significant correlation was found between the results of the STAI questionnaire regarding the state anxiety and the results of the SWLS questionnaire regarding life satisfaction between oncology and non-oncology nurses. In should be noted, however, that non-oncology nurses had a significantly higher STAI trait score compared to oncology nurses $(p=0.0241)$ - Table 1. 
Table 1

Comparative characteristics of the examined group of oncological and non-oncological nurses in terms of the result distribution of the STAI state, STAI trait and SWLS questionnaires

\begin{tabular}{|c|c|c|c|}
\hline & $\begin{array}{l}\text { oncology } \\
(N=60)\end{array}$ & $\begin{array}{l}\text { non-oncology } \\
(\mathrm{N}=30)\end{array}$ & $P$-value \\
\hline STAI state (raw result) & & & $0.4041^{1}$ \\
\hline mean (SD) & $38.7(7.9)$ & $40.2(8.3)$ & \\
\hline range & $21.0-59.0$ & $25.0-58.0$ & \\
\hline median & 38.5 & 39.0 & \\
\hline $95 \% \mathrm{Cl}$ & {$[36.6 ; 40.7]$} & [37.1;43.3] & \\
\hline STAI state (sten) & & & $0.6016^{2}$ \\
\hline mean (SD) & $5.2(1.6)$ & $5.5(1.7)$ & \\
\hline range & $1.0-9.0$ & $2.0-9.0$ & \\
\hline median & 5.0 & 5.0 & \\
\hline $95 \% \mathrm{Cl}$ & {$[4.8 ; 5.6]$} & {$[4.9 ; 6.2]$} & \\
\hline STAl state interpretation & & & $0.3377^{2}$ \\
\hline low & $17(28.3 \%)$ & $6(20.0 \%)$ & \\
\hline medium & $30(50.0 \%)$ & 15 (50.0\%) & \\
\hline high & $13(21.7 \%)$ & $9(30.0 \%)$ & \\
\hline STAI trait (raw result) & & & $0.0241^{1}$ \\
\hline mean $(S D)$ & $39.6(7.4)$ & $43.6(8.1)$ & \\
\hline range & $26.0-61.0$ & $26.0-60.0$ & \\
\hline median & 39.0 & 43.0 & \\
\hline $95 \% \mathrm{Cl}$ & {$[37.7 ; 41.6]$} & {$[40.5 ; 46.6]$} & \\
\hline STAI trait (sten) & & & $0.1298^{2}$ \\
\hline mean (SD) & $3.9(1.6)$ & $4.5(1.8)$ & \\
\hline range & $1.0-8.0$ & $1.0-8.0$ & \\
\hline median & 4.0 & 4.0 & \\
\hline $95 \% \mathrm{Cl}$ & {$[3.5 ; 4.3]$} & [3.8;5.2] & \\
\hline
\end{tabular}




\begin{tabular}{|c|c|c|c|}
\hline & $\begin{array}{l}\text { oncology } \\
(N=60)\end{array}$ & $\begin{array}{l}\text { non-oncology } \\
(\mathrm{N}=30)\end{array}$ & $P$-value \\
\hline STAI trait interpretation & & & $0.2099^{2}$ \\
\hline low & $39(65.0 \%)$ & $16(53.3 \%)$ & \\
\hline medium & $18(30.0 \%)$ & $8(26.7 \%)$ & \\
\hline \multirow[t]{2}{*}{ high } & $3(5.0 \%)$ & $6(20.0 \%)$ & \\
\hline & $\begin{array}{l}\text { oncology } \\
(N=60)\end{array}$ & $\begin{array}{l}\text { non-oncology } \\
(\mathrm{N}=30)\end{array}$ & P-value \\
\hline SWLS (raw result) & & & 0.83301 \\
\hline mean (SD) & $20.2(5.4)$ & $20.4(5.1)$ & \\
\hline range & $8.0-31.0$ & $7.0-31.0$ & \\
\hline median & 20.5 & 20.5 & \\
\hline $95 \% \mathrm{Cl}$ & {$[18.8 ; 21.6]$} & {$[18.5 ; 22.3]$} & \\
\hline SWLS (sten) & & & 0.84211 \\
\hline mean (SD) & $5.5(1.9)$ & $5.5(1.9)$ & \\
\hline range & $1.0-10.0$ & $1.0-10.0$ & \\
\hline median & 5.5 & 5.5 & \\
\hline $95 \% \mathrm{Cl}$ & {$[5.0 ; 5.9]$} & {$[4.8 ; 6.2]$} & \\
\hline SWLS interpretation & & & 0.64702 \\
\hline low & $18(30.0 \%)$ & $8(26.7 \%)$ & \\
\hline medium & $21(35.0 \%)$ & $15(50.0 \%)$ & \\
\hline high & $21(35.0 \%)$ & $7(23.3 \%)$ & \\
\hline
\end{tabular}

Along with the increase in the levels of state anxiety and anxiety trait, the level of life satisfaction decreased - Table 2. 
Table 2

Correlation within the examined group of nurses in terms of the distribution of SWLS questionnaire results and STAI state questionnaire results

\begin{tabular}{|lllllll|}
\hline & \multicolumn{2}{c}{ SWLS (raw result) } & \multicolumn{2}{l}{ SWLS (sten) } & \multicolumn{2}{l|}{ SWLS interpretation } \\
\hline & R & P-value & R & P-value & R & P-value \\
\hline STAl state (raw result) & -0.23 & 0.0294 & -0.23 & 0.0297 & -0.24 & 0.0242 \\
\hline STAl state (sten) & -0.25 & 0.0184 & -0.25 & 0.0193 & -0.26 & 0.0126 \\
\hline STAl state interpretation & -0.25 & 0.0170 & -0.25 & 0.0184 & -0.28 & 0.0068 \\
\hline STAl trait (raw result) & -0.46 & 0.0001 & -0.43 & 0.0001 & -0.44 & 0.0001 \\
\hline STAl trait (sten) & -0.49 & 0.0001 & -0.46 & 0.0001 & -0.47 & 0.0001 \\
\hline STAl trait interpretation & -0.47 & 0.0001 & -0.44 & 0.0001 & -0.45 & 0.0001 \\
\hline
\end{tabular}

Oncology nurses had a significantly lower IL-6 value compared to non-oncology nurses ( $p=0.0001)$, which was associated with a higher percentage of normal IL- 6 values among oncology nurses $(p=$ 0.0001). No statistically significant relationships were found for the remaining parameters - Table 3. 
Table 3

Comparative characteristics of the examined group of nurses in terms of biochemical parameters

\begin{tabular}{|c|c|c|c|}
\hline & $\begin{array}{l}\text { oncology } \\
(N=60)\end{array}$ & $\begin{array}{l}\text { non-oncology } \\
(\mathrm{N}=30)\end{array}$ & $P$-value \\
\hline CRP & & & $0.3125^{1}$ \\
\hline mean (SD) & $2.4(4.4)$ & $2.7(3.1)$ & \\
\hline range & $0.1-31.9$ & $0.3-12.4$ & \\
\hline median & 1.3 & 1.4 & \\
\hline $95 \% \mathrm{Cl}$ & {$[1.3 ; 3.6]$} & {$[1.6 ; 3.9]$} & \\
\hline CRP interpretation & & & $0.4436^{1}$ \\
\hline within the normal value range & $56(93.3 \%)$ & $25(83.3 \%)$ & \\
\hline above normal value range & $4(6.7 \%)$ & $5(16.7 \%)$ & \\
\hline PRL & & & $0.2751^{1}$ \\
\hline mean (SD) & $241.0(98.9)$ & $279.5(136.0)$ & \\
\hline range & $88.0-513.6$ & $96.7-697.3$ & \\
\hline median & 236.3 & 253.4 & \\
\hline $95 \% \mathrm{Cl}$ & {$[215.4 ; 266.5]$} & {$[228.7 ; 330.3]$} & \\
\hline PRL interpretation & & & $0.6106^{1}$ \\
\hline within the normal value range & $60(100.0 \%)$ & $28(93.3 \%)$ & \\
\hline above normal value range & $0(0.0 \%)$ & $2(6.7 \%)$ & \\
\hline Serum cortisol & & & $0.2550^{1}$ \\
\hline mean (SD) & $320.8(135.9)$ & $338.8(121.4)$ & \\
\hline range & $161.0-855.0$ & $118.0-599.0$ & \\
\hline median & 295.0 & 343.0 & \\
\hline $95 \% \mathrm{Cl}$ & {$[285.7 ; 355.9]$} & {$[293.5 ; 384.1]$} & \\
\hline Cortisol serum interpretation & & & $0.9012^{1}$ \\
\hline within the normal value range & $55(91.7 \%)$ & $28(93.3 \%)$ & \\
\hline above normal value range & $5(8.3 \%)$ & $2(6.7 \%)$ & \\
\hline
\end{tabular}




\begin{tabular}{|c|c|c|c|}
\hline & $\begin{array}{l}\text { oncology } \\
(N=60)\end{array}$ & $\begin{array}{l}\text { non-oncology } \\
(\mathrm{N}=30)\end{array}$ & $P$-value \\
\hline Urine cortisol & & & $0.1504^{1}$ \\
\hline mean (SD) & $162.8(194.0)$ & $102.8(159.4)$ & \\
\hline range & $1.0-739.0$ & $1.0-653.0$ & \\
\hline median & 91.5 & 56.0 & \\
\hline $95 \% \mathrm{Cl}$ & {$[112.7 ; 212.9]$} & {$[43.2 ; 162.3]$} & \\
\hline IL-6 & & & $0.0001^{1}$ \\
\hline mean (SD) & $2.1(2.6)$ & $20.3(34.0)$ & \\
\hline range & $1.0-14.2$ & $1.0-177.0$ & \\
\hline median & 1.0 & 9.6 & \\
\hline $95 \% \mathrm{Cl}$ & {$[1.4 ; 2.7]$} & {$[7.6 ; 33.0]$} & \\
\hline IL-6 interpretation & & & $0.0001^{1}$ \\
\hline within the normal value range & $57(95.0 \%)$ & $13(43.3 \%)$ & \\
\hline above normal value range & $3(5.0 \%)$ & $17(56.7 \%)$ & \\
\hline TNFa & & & $0.1266^{1}$ \\
\hline mean (SD) & $7.8(2.3)$ & $18.6(18.9)$ & \\
\hline range & $4.0-16.3$ & $1.0-77.3$ & \\
\hline median & 7.6 & 10.0 & \\
\hline $95 \% \mathrm{Cl}$ & {$[7.3 ; 8.4]$} & {$[11.5 ; 25.6]$} & \\
\hline \multicolumn{4}{|l|}{ TNFa interpretation } \\
\hline within normal value range & $36(60.0 \%)$ & $13(43.3 \%)$ & $0.2007^{1}$ \\
\hline above normal value range & $24(40.0 \%)$ & $17(56.7 \%)$ & \\
\hline
\end{tabular}

An increase in CRP is significantly associated with a decrease in the level of state anxiety. An increase in the PRL description is significantly associated with a decrease in the level of state anxiety. The results are presented in Table 4. 
Table 4

Correlations between state anxiety and biochemical parameters

\begin{tabular}{|lllllll|}
\hline & \multicolumn{2}{l}{ STAl state (raw result) } & \multicolumn{2}{l|}{ STAl state (sten) } & \multicolumn{2}{l|}{ STAl state interpretation } \\
\hline CRP & R & P-value & R & P-value & R & P-value \\
\hline CRP description & -0.25 & 0.0166 & -0.23 & 0.0319 & -0.23 & 0.0299 \\
\hline PRL & -0.32 & 0.0022 & -0.28 & 0.0085 & -0.26 & 0.0145 \\
\hline PRL description & 0.04 & 0.7419 & 0.05 & 0.6392 & 0.03 & 0.7618 \\
\hline Serum cortisol & -0.15 & 0.1474 & -0.16 & 0.1300 & -0.21 & 0.0452 \\
\hline Serum cortisol description & -0.01 & 0.9404 & 0.03 & 0.8122 & 0.01 & 0.9676 \\
\hline Urine cortisol & 0.10 & 0.3672 & 0.05 & 0.6308 & 0.06 & 0.5484 \\
\hline IL-6 & 0.15 & 0.1502 & 0.20 & 0.0550 & 0.19 & 0.0719 \\
\hline IL-6 description & 0.07 & 0.4886 & 0.06 & 0.5434 & 0.12 & 0.2793 \\
\hline TNFa & -0.01 & 0.9041 & -0.02 & 0.8434 & 0.01 & 0.9332 \\
\hline TNFa description & 0.06 & 0.5683 & 0.06 & 0.5759 & 0.06 & 0.5526 \\
\hline
\end{tabular}

An increase in urine cortisol is significantly associated with an increase in the level of trait anxiety (sten) and description.

The increase in IL- 6 is significantly associated with an increase in the level of trait anxiety. An increase in the level of trait anxiety (raw results) is significantly associated with an increase in IL-6, IL-6 interpretation, TNFa and TNFa interpretation. The results are presented in Table 5. 
Table 5

Correlations between trait anxiety and biochemical parameters

\begin{tabular}{|lllllll|}
\hline & \multicolumn{2}{l}{ STAl trait (raw result) } & \multicolumn{2}{l}{ STAl trait (sten) } & \multicolumn{2}{l}{ STAl trait interpretation } \\
\hline & R & P-value & R & P-value & R & P-value \\
\hline CRP & 0.15 & 0.1577 & 0.08 & 0.4606 & 0.03 & 0.8104 \\
\hline CRP description & -0.07 & 0.5254 & -0.07 & 0.5401 & -0.10 & 0.3614 \\
\hline PRL & -0.04 & 0.6833 & 0.02 & 0.8327 & 0.06 & 0.5619 \\
\hline PRL description & -0.16 & 0.1255 & -0.19 & 0.0761 & -0.12 & 0.2700 \\
\hline Serum cortisol & -0.01 & 0.9622 & -0.01 & 0.9351 & -0.04 & 0.6875 \\
\hline Serum cortisol description & -0.03 & 0.7819 & 0.01 & 0.9453 & 0.07 & 0.4941 \\
\hline Urine cortisol & 0.13 & 0.2279 & 0.21 & 0.0478 & 0.25 & 0.0166 \\
\hline IL-6 & 0.32 & 0.0023 & 0.24 & 0.0253 & 0.22 & 0.0412 \\
\hline IL-6 description & 0.21 & 0.0479 & 0.16 & 0.1319 & 0.15 & 0.1616 \\
\hline TNFa & 0.24 & 0.0226 & 0.20 & 0.0559 & 0.14 & 0.1930 \\
\hline TNFa description & 0.24 & 0.0213 & 0.18 & 0.0904 & 0.14 & 0.1925 \\
\hline
\end{tabular}

\section{Discussion}

Earlier studies conducted in Lithuania and Hong Kong indicate a relatively low level of stress among primary care nurses [Galdikienè et al.], [Lee] and satisfaction with the content of their work but it needs to be noted that insufficient salaries and poor working conditions affect the levels of perceived job satisfaction [Delobelle et al.]. In our research, the level of satisfaction with life was within the population norm for Poland. In addition, no statistically significant differences were found between the level of life satisfaction of primary health care nurses and oncology nurses. Research conducted in China and Turkey indicates a low level of satisfaction among oncology nurses [Wang et al.], [Ergün et al.]. In research conducted by Piotrkowska et al, the lower level of life satisfaction was associated with shift patterns, which was not demonstrated in our research. Another contributing factor is additional work outside the primary employment institution [Piotrkowska et al.].

In Poland, primary health care nurses showed low to medium level of occupational burnout [WilczekRużyczka, Plewa], [Dębska, Cepuch]. In another study, the level of emotional exhaustion and depersonalization in the primary care nurses group was higher than in other studied specializations (intensive care, surgery, internal medicine). What is more, nurses from this group more often reported psychological burden in many dimensions (low satisfaction, problems and conflicts, monotony, feeling overwhelmed, dulling work, nervousness) than other nurses [Dębska et al.]. In our research, the group of 
primary health care nurses presented a higher level of trait anxiety, which translates to susceptibility to stress.

A meta-analysis of Polish studies on coping with stress among Polish nurses showed that the most popular approach was task-focused [Kwak et al.], which is considered the most effective because it addresses the cause of stress. However, it should be noted that this meta-analysis involved a relatively small number of publications. Studies by Turkish scientists also indicate that oncology nurses usually manage stress effectively [Isikhan et al.]. The studies of primary health care nurses also indicate that effective stress coping styles predominate in this professional group [Dębska, Cepuch] and in the group of oncology nurses [Marciniak, Ślusarska et al.].

What may seem surprising, serum and urine cortisol levels do not correlate with the studied psychological parameters. However, the results obtained by other researchers are not conclusive. In some studies, such a positive correlation was proved [Schulz et al.], [Janota, Załuska], [Evolahti et al.]. No relationship between cortisol levels and psychosocial parameters was reported by some researchers [Takatsuji et al.], [Fischer et al.], [Gerra et al.]. One Norwegian study found no relationship between psychosocial factors at work and cortisol levels in saliva samples collected at 8 am among nurses. However, such relationships were observed in the samples collected in the afternoon and evening. The result of the study was also affected by smoking and drinking coffee [Harris et al.]. Also, the conclusions from the meta-analysis of research into salivary cortisol level and perceived stress indicate that this relationship is weak [Hjortskov et al.].

Biochemical markers of psychological stress have been studied in nurses. One of such studies, which was conducted in Brazil on 57 nurses, revealed that cortisol values were higher on a working day than on a non-working day. Nurses who worked double working days showed higher levels of cortisol [Pires de Rocha et al.].

A study by Wingenfeld et al. assessed the effect of burnout on salivary cortisol levels. It included 279 German nurses. The Maslach Burnout Inventory (MBI) was used to assess occupational burnout. Nurses who met two of the three burnout criteria (emotional exhaustion, depersonalization and a reduced sense of personal accomplishment) showed higher levels of cortisol released during the day as compared to nurses who met one or no criteria [Wingenfeld et al.]. Our study did not reveal a relationship between serum cortisol levels and state anxiety or trait anxiety as per STAI. A study conducted by Noto et al. did not show a correlation between the level of anxiety and salivary cortisol and chromogranin $A$ concentration. However, a correlation was reported between salivary amylase and anxiety - salivary amylase level increased when questionnaire-assessed anxiety increased, too [Noto et al.]. A study conducted among skydivers showed that people who had more experience in parachuting had a more severe response to acute stress manifested by an increase in serum corticotropin and cortisol levels than those who took the jump for the first time, or their experience was small [Kowalczyk, Chicken]. It is worth noting that the markers of the hypothalamic-pituitary-adrenal axis stabilize in response to repetitive stress 
stimuli [Foley, Kirschbaum], [von Känel et al.]. The lack of a similar relationship in our research may be due to the fact that nurses experience chronic stress in everyday work [Grochowska et al.].

The level of objectively assessed stress does not need to be related to the subjectively assessed level. A prospective cohort Swiss study, which included 82 nurses, found a relationship between subjectively measured stress and salivary cortisol levels. Samples for testing were taken in three 9-day periods. Subjects with higher levels of stress showed higher levels of cortisol. However, no relationship was found between objectively measured stress and salivary cortisol concentration [Metzenthin et al.]. One study concerned the psychological and biochemical assessment of stress and involved a group of 514 nurses who responded to questions designed to create criteria for the objective assessment of stress. Of these, 38 nurses were selected and given weekly blood and saliva biochemical tests over 9 months. Salivary leukocyte count and TNF-a, IL1 $\beta$, IFN- $\gamma$, cortisol and immunoglobulin A $(\operatorname{IgA})$ levels were determined in the tested samples. Individuals with high levels of objectively assessed stress had lower leukocyte count than those with low levels of stress, while salivary IgA was higher in those with higher stress levels. The TNF-a level was on the border of statistical significance and its values were lower in subjects with a higher level of objective stress. Subjectively assessed stress did not affect the level of the studied parameters including cortisol [Lee et al.].

A British study which included 315 nursing staff members of both sexes assessed urinary cortisol and catecholamines - adrenaline and noradrenaline. All hormone levels were higher in the male group. It was also shown that their level increased with age in both sexes. In women receiving hormone replacement therapy (HRT), all tested hormone levels were lower than in women of a similar age who did not receive HRT [Deane et al.].

In the study assessing depression and distress versus interleukin 6 concentration, a statistically significant positive correlation was reported between those aspects [Lutgendorf et al.]. Similar results were obtained among persons diagnosed with post-traumatic stress disorder compared to the control group [Maes et al.]. Childhood events can play a role in the immune response to stress. Subjects who were abused as children had higher IL-6 levels in response to acute stress compared to the control group [Carpenter et al.]. An increase in IL-6 in response to a stress stimulus has also been observed in laboratory animals [Chourbaji et al.]. In the study in which the level of cytokines was assessed in patients with bipolar disorder in a manic episode, an increase in IL-6 levels was observed, while TNFa levels were not significantly different in remission or in comparison with the control group. In the depressive episode, no relationship was observed between these cytokines [Remlinger-Molenda et al.].

An American study which included 26 patients with advanced cancer and 26 caregiver family members showed that stress levels were associated with increased levels of salivary cortisol and interleukin 6 . The subjects were included in the Mindfulness-Based Stress Reduction program (MBSR). STAI and PSS 10 questionnaires were also used in this study, and the SF-36 survey was used to assess the quality of life. After participating in the program, both patients and their caregivers exhibited lower levels of anxiety (both state and trait), stress, and salivary cortisol and IL-6 [Lengacher et al.]. Also, another study of 
oncology nurses indicates that mindfulness interventions can significantly reduce stress and burnout levels and have a positive effect on the subjects' overall well-being [Duarte, Pinto-Gouveia]. Falco et al. also come to similar conclusions and confirm that work-related stress is caused by the features of the work environment which trigger pathophysiological reactions. They assessed the impact of work requirements and work resources as per the job demands-resources model on interleukin 6 values in health care workers, including nurses. Subjects with high work autonomy and high interpersonal conflict at work had lower IL-6 levels compared to subjects with low work autonomy and high interpersonal conflict. The IL- 6 value was moderated by emotional requirements, autonomy at work and social support [Falco et al.]. Also a study by Arnetz et al. indicates a positive correlation between stress levels and serum interleukin 6 [Arnetz et al.].

It should be noted that IL- 6 levels are higher in response to stress when more time has elapsed between stress exposure and sample collection, which suggests that the immune response to stress is spread over time [Rohleder et al.]. Moreover, IL-6 secretion is not modified in response to stress [von Känel et al.], which may suggest the reasons for the correlation observed in our study.

Despite the effect of interleukin 6 on serum C-reactive protein levels, only a negative correlation between CRP levels and state anxiety was observed in our study. It is difficult to assess this correlation because Creactive protein is not secreted immediately in response to IL-6. Some studies indicate a positive correlation between stress levels and serum C-reactive protein levels [Hapuarachchi et al.], [Xu et al.], [Liukkonen et al.], [Hamer et al.]. It should be noted that some studies do not associate the level of Creactive protein with stress [Labad et al.], [Baumert et al.], which was also the observation made in a large meta-analysis [Marsland et al.]. There are studies which indicate a marginal association [Steptoe et al.].

There is some evidence that prolactin is sensitive to stress stimulus [Lennartsson], [Sobrinho et al.], [Sabioncello et al.]. However, there are also reports of contradictory findings [Matalka et al.], [Marquez et al.], [Munro et al.]. No such correlations were observed in our analysis, which may partly be due to the fact that shift work may also interfere with prolactin secretion [Touitou et al.], [Weibel, Brandenberger], although there are available research results which do not confirm this influence [Korompeli et al.]. Research conducted among Swedish women on sick leave and health care workers showed that their levels of prolactin were lower those in the control group of healthy people, but only the difference between the participants on sick leave and the control group was statistically significant. No statistically significant differences in tumour necrosis factor a concentration were found in this study. The interleukin 6 result was on the border of statistical significance. In this study, significant differences were found in the levels of EGF (epidermal growth factor), MCP1 (monocyte chemoattractant protein) and VEGF (vascular endothelial growth factor). The authors of this study suggest that the last three parameters mentioned above can be used in screening for psychosocial stress among women [Åsberg et al.].

The impact of stress on the level of tumour necrosis factor a is not clear. Studies conducted by Indian researchers have shown that TNFa levels were lower among people with high levels of anxiety as measured with the STAI questionnaire. Our research indicates the opposite - a higher level of trait anxiety 
was associated with an increase in TNFa concentration, while state anxiety was not associated with its concentration. Many studies indicate its increase in response to stress [Prather et al.], in D-type personality [Denollet et al.], during acute sleep deprivation [Chennaoui et al.], and even a significant increase in TNFa among lonely people [Jaremka et al.]. In addition, it has been shown that stress response may not be associated with an increased level of TNFa [Grassi-Oliveira] but an increased concentration of soluble receptors for this factor [Slavich et al.], [Conraads et al.] [Denollet et al.], [GrassiOliveira].

It should be mentioned that there are effective methods to reduce stress among nurses and their efficiency was confirmed by biochemical tests. In a study in Taiwan, 54 randomly selected nurses whose work experience was shorter than a year were assessed for stress with the use of a 10-point VAS scale and serum cortisol tests. Heart rate, blood pressure and finger temperature values were also recorded. The baseline average cortisol level was $9.97 \mu \mathrm{g} / \mathrm{dL}$ in the group of nurses who then were given an intervention treatment i.e. resting and listening to music for 30 minutes. The average cortisol level after the intervention was $4.97 \mu \mathrm{g} / \mathrm{dL}$. The perceived stress, blood pressure and heart rate values were significantly lower, while body temperature was higher. The average cortisol level in our study was $11.82 \mu \mathrm{g} / \mathrm{dL}$ [Lai, Li]. Another study, which assessed the effect of music on stress levels, included 60 nurses who were divided into three groups: listening to calm music, listening to stimulating music and quietly resting. State and trait anxiety was assessed in the STAI questionnaire. In addition, pulse rate, blood pressure, interleukin 6, interleukin 10 and tumour necrosis factor a were assessed. In this group of patients, cytokines values were below measurable. Of all remaining parameters, only arterial pressure was higher in the subjects who listened to stimulating music as compared to the group listening to calm music [Lai et al.].

\section{Conclusions}

The study showed a relationship between anxiety - trait and the level of tested cytokines - interleukin 6 and tumour necrosis factor a. Higher levels of anxiety - trait were associated with higher levels of the tested cytokines in both study groups of nurses. Both anxiety - state and anxiety - trait were associated with a decrease in life satisfaction among the surveyed nurses. Primary health care nurses were characterized by a higher level of trait anxiety than oncological nurses. This suggests that nurses with a higher level of trait anxiety choose allegedly safer and less burdensome work environment.

To counteract the effects of occupational stress, nurses should use verified psychological strategies as well as relaxation techniques which can significantly reduce the level of anxiety and improve the values of biochemical markers which correlate with it.

\section{Abbreviations}

ACTH

adrenocorticotropic hormone 
$\mathrm{CRH}$

corticotropin-releasing hormone

CRP

C-reactive protein

IFNy

Interferon gamma

IL-1

Interleukin 1

IL1 $\beta$

Interleukin 1 beta

IL-6

Interleukin 6

PSS-10

10-item Perceived Stress Scale

STAI

State-Trait Anxiety Inventory

SWLS

Satisfaction With Life Scale

TNFa

Tumor Necrosis Factora

\section{Declarations}

\section{Ethics approval and consent to participate}

The study was conducted after obtaining approval from the Independent Bioethics Commission for Research at the Medical University of Gdańsk (NKBBN / 411 / 2015-2016). Obtaining the consent of the management of the institutions where the study was conducted was an obligatory condition. The participation in the study was voluntary and required the informed consent of respondents.

\section{Consent for publication}

Not applicable.

\section{Availability of data and material}

The datasets used and/or analysed during the current study are available from the corresponding author on reasonable request. 


\section{Competing interests}

Not applicable.

\section{Funding}

No external funding.

\section{Authors' contributions}

Przemysław Domagała - 70\%

Aleksandra Gaworska-Krzemińska - 30\%

\section{Acknowledgements}

Not applicable.

\section{References}

Åsberg M., Nygren Å., Leopardi R., Rylander G., Peterson U., et al. Novel Biochemical Markers of Psychosocial Stress in Women. PLOS ONE 2009. 4(1): e3590.

Atreya R., Neurath MF. Involvement of IL-6 in the pathogenesis of inflammatory bowel disease and colon cancer. Clin Rev Allergy Immunol 2005. 28: 187-196.

Arican O., Aral M., Sasmaz S., Ciragil P. Serum levels of TNF-alpha, IFN-gamma, IL-6, IL-8, IL-12, IL-17, and IL-18 in patients with active psoriasis and correlation with disease severity. Mediat Inflammation 2005. 2005: 273-279.

Arnetz J., Sudan S., Goetz C., Counts S., Arnetz B. Nurse work environment and stress biomarkers: possible implications for patient outcomes. J Occup Environ Med 2019. 61: 676-681.

Baumert J., Lukaschek K., Kruse J., Emeny RT., Koenig W., et al. No evidence for an association of posttraumatic stress disorder with circulating levels of CRP and IL-18 in a population-based study. Cytokine 2013. 63: 201-208.

Beck CT. Secondary Traumatic Stress in Nurses: A Systematic Review. Arch Psychiatr Nurs 2011. 25(1): 110. 
Carpenter LL., Gawuga CE., Tyrka AR., Lee JK., Anderson GM., et al. Association between plasma IL-6 response to acute stress and early-life adversity in healthy adults. Neuropsychopharmacology 2010. 35: 2617-2623.

Chennaoui M., Sauvet F., Drogou C., Van Beers P., Langrume C., et al. Effect of one night of sleep loss on changes in tumor necrosis factor alpha (TNF-alpha) levels in healthy men. Cytokine 2011. 56: 318-324.

Chourbaji S., Urani A., Inta I., Sanchis-Segura C., Brandwein C., et al. IL-6 knockout mice exhibit resistance to stress-induced development of depression-like behaviors. Neurobiol Dis 2006. 23: 587-594.

Chu WM. Tumor necrosis factor. Cancer Lett 2013. 328(2): 222-225.

Conraads VM., Denollet J., De Clerck LS., Stevens WJ., Bridts C., et al. Type D personality is associated with increased levels of tumour necrosis factor (TNF)-alpha and TNF-alpha receptors in chronic heart failure. Int J Cardiol 2006. 113(1):34-38.

Deane R., Chummun H., Prashad D. Differences in urinary stress hormones in male and female nurses at different ages. J Adv Nurs 2002. 37: 304-310.

De Lauretis A., Sestini P., Pantelidis P., Hoyles R., Hansell DM., et al. Serum interleukin 6 is predictive of early functional decline and mortality in interstitial lung disease associated with systemic sclerosis. $J$ Rheumatol 2013. 40(4): 435-446.

Delobelle P., Rawlinson JL., Ntuli S., Malatsi I., Decock R., et al. Job satisfaction and turnover intent of primary healthcare nurses in rural South Africa: a questionnaire survey. J Adv Nurs 2011. 67: 371-383.

Denollet J., Vrints CJ., Conraads VM. Comparing type D personality and older age as correlates of tumor necrosis factor-a dysregulation in chronic heart failure. Brain Behav Immun 2008. 22: 736-743.

Dębska G., Cepuch G. Wypalenie zawodowe u pielęgniarek pracujących w zakładach podstawowej opieki zdrowotnej. Probl Pielęg 2008. 16(3): 273-279.

Dębska G., Pasek M., Wilczek-Rużyczka E. Obciążenia psychiczne i wypalenie zawodowe u pielęgniarek pracujących w różnych specjalnościach zawodowych. Hygeia Public Health 2014. 49(1): 113-119.

Domagała P., Gaworska-Krzemińska A. Stress and burnout among oncology nurses: review study. Pol Psychol Bull 2018. 49(4): 482-488.

Duarte J., Pinto-Gouveia J. Effectiveness of a mindfulness-based intervention on oncology nurses' burnout and compassion fatigue symptoms: A non-randomized study. International Journal of Nursing Studies 2016. 64: 98-107.

Emilia I., Gómez-Urquiza J. L., Cañadas G. R., Albendín-García L., Ortega-Campos E., et al. Burnout and its relationship with personality factors in oncology nurses. European Journal of Oncology Nursing 2017. 30 : 
91-96.

Emold C., Schneider N., Meller I., Yagil Y. Communication skills, working environment and burnout among oncology nurses. European Journal of Oncology Nursing 2011. 15(4): 358-363.

Ergün FS., Oran NT., Bender CM.. Quality of life of oncology nurses. Cancer Nursing 2005. 28(3): 193-199.

Esler M., Eikelis N., Schlaich M., Lambert G., Alvarenga M., et al. Chronic mental stress is a cause of essential hypertension: presence of biological markers of stress. Clin Exp Pharmacol Physiol 2008. 35: 498-502.

Evolahti A., Hultcrantz M., Collins A. Women's work stress and cortisol levels: a longitudinal study of the association between the psychosocial work environment and serum cortisol. J Psychosom Res 2006. 61: 645-652.

Falco A., Dal Corso L., Girardi D., De Carlo A., Comar M. The moderating role of job resources in the relationship between job demands and interleukin- 6 in an Italian healthcare organization. Res Nurs Health 2018. 41: 39-48.

Fischer JE., Calame A., Dettling AC., Zeier H., Fanconi S. Experience and endocrine stress responses in neonatal and pediatric critical care nurses and physicians. Crit Care Med 2000. 28: 3238-3281.

Foley P., Kirschbaum C. Human hypothalamus-pituitary-adrenal axis responses to acute psychosocial stress in laboratory settings. Neurosci Biobehav Rev 2010. 35(1): 91-96.

Galdikienè N., Asikainen P., Balčiūnas S., Suominen T. Do nurses feel stress?. Nurs Health Sci 2014. 16: 327-334.

Gerra G., Zaimovic A., Zambelli U., Timpano M., Reali N., et al. Neuroendocrine responses to psychological stress in adolescents with anxiety disorder. Neuropsychobiology 2000. 42: 82-92.

Glaser R., Kiecolt-Glaser JK. Stress induced immune disfunction: implications for health. Nat Rev Immunol 2005. 5(3): 243-251.

Gołąb J., Jakóbisiak M., Firczuk M. Psychoneuroimmunologia. W: Gołąb J., Jakóbisiak M., Lasek W., Stokłosa T. (red.). Immunologia. Wydawnictwo Naukowe PWN. Warszawa 2017. 279-287.

Gomez-Urquiza JL., Aneas-Lopez AB., la Fuente-Solana D., Emilia I., Albendín-García L., et al. Prevalence, risk factors, and levels of burnout among oncology nurses: a systematic review. Oncology Nursing Forum 2016. 43(3): E104-E120.

Grassi-Oliveira R., Brietzke, E., Pezzi JC., Lopes RP., Teixeira AL., et al. Increased soluble tumor necrosis factor-a receptors in patients with major depressive disorder. Psychiatry Clin Neurosci 2009. 63: 202-208. 
Grochowska A., Bodys-Cupak I., Korus M. Sposoby radzenia sobie z trudnościami przez pielęgniarki pracujące na oddziałach pediatrycznych. Pielęg Pol 2017. 63(1): 97-104.

Grygorczuk A. Pojęcie stresu w medycynie i psychologii. Psychiatria 2008. 5(3): 111-115.

Hamer M., Williams E., Vuonovirta R., Giacobazzi P., Gibson EL., et al. The effects of effort-reward imbalance on inflammatory and cardiovascular responses to mental stress. Psychosom Med 2006. 68(3): 408-413.

Hapuarachchi JR., Chalmers AH., Winefield AH., Blake-Mortimer JS. Changes in clinically relevant metabolites with psychological stress parameters. Behav Med 2003. 29: 52-59.

Harris TB., Ferrucci L., Tracy RP., Corti MC., Wacholder S., et al. Associations of elevated interleukin-6 and C-reactive protein levels with mortality in the elderly. Am J Med 1999. 106(5): 50

Heszen I. Psychologia stresu. Wydawnictwo naukowe PWN. Warszawa 2013.

Hjortskov N., Garde AH., Ørbæk P., Hansen ÅM. Evaluation of salivary cortisol as a biomarker of selfreported mental stress in field studies. Stress Health 2004. 20: 91-98.

Isikhan V., Comez T., Danis MZ. Job stress and coping strategies in helath care professionals working with cancer patients. Eur J Oncol Nurs 2004. 8: 234-244.

Janota B., Załuska M. Poziom kortyzolu, dehydroepiandrosteronu i jego siarczanu (DHEA i DHEA-S) w surowicy krwi a obraz lipidogramu i reakcja na leczenie u kobiet z depresją. Psychiatr Pol 2011. 45(6): 861-873.

Jarczok MN., Jarczok M., Mauss D., Koenig J., Li J., et al. Autonomic nervous system activity and workplace stressors - a systematic review. Neurosci Biobehav Rev 2013. 37(8): 1810-1823.

Jaremka LM., Fagundes CP., Peng J., Bennett JM., Glaser R., et al. Loneliness promotes inflammation during acute stress. Psychol Sci 2013. 24(7): 1089-1097.

Jin P., Yeung AS., Tang TO., Low R. Identifying teachers at risk in Hong Kong: Psychosomatic symptoms and sources of stress. Journal of psychosomatic research 2008. 65(4): 357-362.

Kane PP. Stress causing psychosomatic illness among nurses. Indian Journal of occupational and environmental medicine 2009. 13(1): 28.

Kern PA., Ranganathan S., Li C., Wood L., Ranganathan G. Adipose tissue tumor necrosis factor and interleukin-6 expression in human obesity and insulin resistance. Am J Physiol Endocrinol Metab 2001. 280(5): E745-E751.

Khamisa N., Oldenurg B., Peltzer K., llic D. Work Related Stress, Burnout, Job Satisfaction and General Health of Nurses. International Journal of Environmental Research and Public Health 2015. 12(1): 652- 
666.

Kliszcz J., Nowicka-Sauer K., Trzeciak B., Sadowska A. Poziom lęku, depresji i agresji u pielęgniarek, a ich satysfakcja z życia i pracy zawodowej. Med Pr 2004. 55 (6): 461-468.

Korompeli A., Sourtzi P., Tzavara C., Velonakis E. Rotating shift-related changes in hormone levels in intensive care unit nurses. J Adv Nur 2009. 65(6): 1274-1282.

Kowalczyk E., Kura M. Wpływ stresu związanego ze skokami spadochronowymi na stężenie ACTH i kortyzolu w surowicy krwi. Psychiatr Pol 2012. 46(5): 731-742.

Kwak M., Zaczyk I., Wilczek-Rużyczka E. Stres i style radzenia sobie z nim przez polskie pielęgniarki metaanaliza badań. Med Og Nauk Zdr 2018. 24(2): 120-125.

Labad J., Stojanovic-Pérez A., Montalvo I., Solé M., Cabezas Á., et al. Stress biomarkers as predictors of transition to psychosis in at-risk mental states: roles for cortisol, prolactin and albumin. J Psychiatr Res 2015. 60: 163-169.

Lai H., Li Y. The effect of music on biochemical markers and self perceived stress among first line nurses: a randomized controlled crossover trial. J Adv Nurs 2011. 67(11): 2414-2424.

Lai H., Liao K., Huang C., Chen P., Peng T. Effects of Music on Immunity and Physiological Responses in Healthcare Workers: A Randomized Controlled Trial. Stress Health 2013. 29(2): 91-98.

Landowski J. Neurobiologia reakcji stresowej. Neuropsychiatr Neuropsychol 2007. 2(1): 26-36.

Lee JK. Job stress, coping and health perceptions of Hong Kong primary care nurses. Int J Nurs Pract 2003. 9(2): 86-91.

Lee KM., Kang D., Yoon K., Kim SY., Kim H., et al. A pilot study on the association between job stress and repeated measures of immunological biomarkers in female nurses. Int Arch Occup Environ Health 2010. 83(7): 779-789.

Lengacher CA., Kip KE., Barta M., Post-White J., Jacobsen PB., et al. A pilot study evaluating the effect of mindfulness-based stress reduction on psychological status, physical status, salivary cortisol, and interleukin-6 among advanced-stage cancer patients and their caregivers. J Holist Nurs 2012. 30(3): 170185.

Lennartsson AK., Jonsdottir IH. Prolactin in response to acute psychosocial stress in healthy men and women. Psychoneuroendocrinology 2011. 36(10): 1530-1539.

Liukkonen T., Rasanen P., Jokelainen J., Leinonen M., Järvelin MR., et al. The association between anxiety and C-reactive protein (CRP) levels: results from the Northern Finland 1966 birth cohort study. Eur Psychiatry 2011. 26(6): 363-369. 
Lutgendorf SK., Garand L., Buckwalter KC., Reimer TT., Hong SY., et al. Life stress, mood disturbance, and elevated interleukin-6 in healthy older women. J Gerontol A Biol Sci Med Sci 1999. 54(9): M434-439.

Maes M., Lin AH., Delmeire L., Van Gastel A., Kenis G., et al. Elevated serum interleukin-6 (IL-6) and IL-6 receptor concentrations in posttraumatic stress disorder following accidental man-made traumatic events. Biol Psychiatry 1999. 45(7): 833-839.

Marciniak A., Grześk G., Koziński M., Grześk E., Kubica J. Zmienność dobowa w układzie hemostazy. Folia Cardiol 2010. 5(1): 1-7.

Marquez C., Nadal R., Armario A. Influence of reactivity to novelty and anxiety on hypothalamic-pituitaryadrenal and prolactin responses to two different novel environments in adult male rats. Behav Brain Res 2006. 168(1): 13-22.

Marsland AL., Walsh C., Lockwood K., John-Henderson NA. The effects of acute psychological stress on circulating and stimulated inflammatory markers: A systemic review and meta-analysis. Brain Behav Immun 2017. 64: 208-219.

Maslach C., Schaufeli WB., Leiter MP. Job burnout. Annual review of psychology 2001. 52(1): 397-422.

Matalka K., Sidki A., Abdul-Malik S., Thewaini A. Academic stress-Influence on Epstein-Barr virus and cytomegalovirus reactivation, cortisol, and prolactin. Lab Medicine 2000. 31(3): 163-168.

Metzenthin P., Helfricht S., Loerbroks A., Terris DD., Haug HJ., et al. A one-item subjective work stress assessment tool is associated with cortisol secretion levels in critical care nurses. Prev Med 2009. 48(5): 462-466.

Munro CA., Oswald LM., Weerts EM, McCaul ME., Wand GS. Hormone Responses to Social Stress in Abstinent Alcohol-Dependent Subjects and Social Drinkers with No History of Alcohol Dependence. Alcohol Clin Exp Res 2005. 29(7): 1133-1138.

Noto Y., Sato T., Kudo M., Kurata K., Hirota K. The relationship between salivary biomarkers and StateTrait Anxiety Inventory Score dunder mental arithmetic stress: a pilot study. Anesth Analg 2005. 101(6): 1873-1876.

Nyklewicz W., Krajewska-Kułak E. Śmierć a emocje pielęgniarek - doniesienia wstępne. Probl Pielęg 2008. 16(3): 248-254.

Ogińska-Bulik N. Stres zawodowy w zawodach usług społecznych. Centrum Doradztwa i Informacji Difin. Warszawa 2006.

Padgett D., Glaser R. How stress influences the immune response. Trends Immunol 2003. 24(8): 444448. 
Piotrkowska R., Jarzynkowski P., Książek J., Mędrzycka-Dąbrowska W. Satisfaction with life of oncology nurses in Poland. International Nursing Review2019. 66: 374-380.

Pires da Rocha MC., Figueiredo de Martino MM., Grassi-Kassisse DM., Luiz de Souza A. Stress among nurses: an examination of salivary cortisol levels on work and day off. Rev Esc Enferm USP 2013. 47(5): 1194-1201.

Potocka A. Stres - natura zjawiska. W: Waszkowska M., Potocka A., Wojtaszczyk P. (red.). Miejsce pracy na miarę oczekiwań. Poradnik dla pracowników socjalnych. Instytut Medycyny Pracy im. prof. J. Nofera. Łódź 2010. 9-44.

Potter P., Deshields T., Divanbeigi J., Berger J., Cipriano D., et al. Compassion fatigue and burnout: prevalence among oncology nurses. Clinical journal of oncology nursing 2010. 14: E56-62.

Remlinger-Molenda A., Wójciak P., Michalak M., Rybakowski J. Ocena aktywności wybranych cytokin w epizodzie maniakalnym i depresyjnym choroby afektywnej dwubiegunowej. Psychiat Pol 2012. 46(4): 599-611.

Rohleder N., Aringer M., Boentert M. Role of interleukin-6 in stress, sleep, and fatigue. Ann N Y Acad Sci 2012. 1261: 88-96.

Roberti JW., Harrington LN., Storch EA. Further Psychometric Support for the 10-Item Version of the Perceived Stress Scale. J Coll Couns 2006. 9: 135-147.

Sabioncello A., Kocijan-Hercigonja D., Rabatić S., Tomasić J., Jeren T., et al. Immune, endocrine, and psychological responses in civilians displaced by war. Psychosom Med 2000. 62(4): 502-508.

Sabry A, Sheashaa H, El-Husseini A., Mahmoud K., Eldahshan KF., et al. Proinflammatory cytokines (TNFalpha and IL-6) in Egyptian patients with SLE: its correlation with disease activity. Cytokine 2006, 35(3-4): 148-153.

Samaha E., Lal S., Samaha N., Wyndham J. Psychological, lifestyle and coping contributors to chronic fatigue in shift-worker nurses. J Adv Nurs 2007. 59(3): 221-232.

Schulz P., Kirschbaum C., Prüßner J., Hellhammer D. Increased free cortisol secretion after awakening in chronically stressed individuals due to work overload. Stress Health 1998. 14(2): 91-97.

Sęk H. Poznawcze i kompetencyjne uwarunkowania wypalenia w pracy z chorymi. Post Psychiatr Neurol 2005. 14(2): 93-98.

Slavich GM., Way BM., Eisenberger NI., Taylor SE. Neural sensitivity to social rejection is associated with inflammatory responses to social stress. Proc Natl Acad Sci USA 2010. 107(33): 14817-14822. 
Służewska A., Rybakowski JK., Laciak M., Mackiewicz A., Sobieska M., et al. Interleukin-6 serum levels in depressed patients before and after treatment with fluoxetine. Ann N Y Acad Sci 1995. 762: 474-476.

Sobrinho LG., Simoes M., Barbosa L., Raposo J. F., Pratas S., et al. Cortisol, prolactin, growth hormone and neurovegetative responses to emotions elicited during an hypnoidal state. Psychoneuroendocrinology 2003. 28(1): 1-17.

Steptoe A., Hamer M., Chida Y. The effects of acute psychological stress on circulating inflammatory factors in humans: A review and meta-analysis. Brain Behav Immun 2007. 21(7): 901-912.

Stokłosa T. Psychoneuroimmunologia. W: Gołąb J., Jakóbisiak M., Lasek W., Stokłosa T. (red.). Immunologia. Wydawnictwo Naukowe PWN. Warszawa 2017. 279-287.

Su D., Li Z., Li X., Chen Y., Zhang Y., et al. Association between serum interleukin-6 concentration and mortality in patients with coronary artery disease. Mediators Inflamm 2013. 2013: article ID 726178.

Takatsuji K., Sugimoto Y., Ishizaki S., Ozaki Y., Matsuyama E. The effects of examination stress on salivary cortisol, immunoglobulin A, and chromogranin A in nursing students. Biomed Res 2008. 29(4): 221-224.

Terelak J.F. Stres psychologiczny. Oficyna Wydawnicza Branta. Bydgoszcz 1995.

Toh SG., Ang E., Devi MK. Systematic review on the relationship between the nursing shortage and job satisfaction, stress and burnout levels among nurses in oncology/haematology settings. Int J Evid Based Healthc 2012. 10(2): 126-141.

Touitou Y., Motohashi Y., Reinberg A., Touitou C., Bourdeleau P., et al. Effect of shift work on the night-time secretory patterns of melatonin, prolactin, cortisol and testosterone. Eur J Appl Physiol Occup Physiol 1990. 60(4): 288-292.

Visser M., Pahor M., Taaffe DR., Goodpaster BH., Simonsick EM., et al. Relationship of Interleukin-6 and Tumor Necrosis Factor-a With Muscle Mass and Muscle Strength in Elderly Men and Women: The Health ABC Study. J Gerontol A Biol Sci Med Sci 2002. 57(5): M326-332.

von Känel R., Kudielka BM., Preckel D., Hanebuth D., Fischer JE. Delayed response and lack of habituation in plasma interleukin-6 to acute mental stress in men. Brain Behav Immun 2006. 20(1): 40-48.

Wang J., Okoli CTC., He H., Feng F., Li J., Zhuang L., Lin M. Factors associated with compassion satisfaction, burnout, and secondary traumatic stress among Chinese nurses in tertiary hospitals: A cross-sectional study. International Journal of Nursing Studies 2020. 102: 103472.

Weibel L., Brandenberger G. Disturbances in hormonal profiles of night workers during their usual sleep and work times. J Biol Rhythms 1998. 13(3): 202-208. 
Werka T., Zagrodzka J. Strach i lęk w świetle badań neurobiologicznych. W: Fajkowska M., Szymura B. (red.). Lęk: geneza, mechanizmy, funkcje. Wydawnictwo Naukowe Scholar. Warszawa 2009. 17-49.

West C., Huschka M., Novotny P., Sloan J.A., Kolars J.C., et al. Association of perceived medical errors with resident distress and empathy: a prospective longitudinal study. JAMA 2006. 296(9): 1071-1078

Wilczek-Rużyczka E. Wypalenie zawodowe pracowników medycznych. Wolters Kluwer. Warszawa 2014.

Wilczek-Rużyczka E., Plewa Z. Wypalenie zawodowe u pracowników ochrony zdrowia. Medycyna Rodzinna 2008. 3: 69-73.

Wingenfeld K., Schulz M., Damkroeger A., Rose M., Driessen M. Elevated diurnal salivary cortisol in nurses is associated with burnout but not with vital exhaustion. Psychoneuroendocrinology 2009. 34(8): 11441151.

Wrześniewski K., Sosnowski T., Jaworowska A., Fecenec D. Inwentarz Stanu i Cechy Lęku. Polska adaptacja STAl. Podręcznik. Pracownia Testów Psychologicznych Polskiego Towarzystwa Psychologicznego. Warszawa 2011.

Xu W., Chen B., Guo L., Li Z., Zhao Y., et al. High-sensitivity CRP: Possible link between job stress and atherosclerosis. Am J Ind Med 2015. 58(7): 773-779.

Yu H., Jiang A., Shen J. Prevalence and predictors of compassion fatigue, burnout and compassion satisfaction among oncology nurses: A cross-sectional survey. International Journal of Nursing Studies 2016. 57: 28-38.

Yudkin JS., Kumari M., Humphries SE., Mohamed-Ali V. Inflammation, obesity, stress and coronary heart disease: is interleukin-6 the link? Atherosclerosis 2000. 148(2): 209-214.

Zimecki M., Artym J. Wpływ stresu psychicznego na odpowiedź immunologiczną. Post Hig Med Dosw 2004. 58: 166-175. 